\title{
Competitiveness of Halal Industry in Maghreb Countries
}

\author{
Mohammed Rizki Moi (Corresponding author) \\ Faculty of Economics and Management, Universiti Kebangsaan Malaysia, \\ 43600 Bangi, Selangor, Malaysia \\ $\&$
}

Faculty of Management and Muamalah, International Islamic University College Selangor (KUIS), Bandar Seri Putra, 43000 Kajang, Selangor, Malaysia

Tel: +603-8921 5373 E-mail: rizkiukm@gmail.com

Mohd Ali Mohd Noor

Faculty of Economics and Management, Universiti Kebangsaan Malaysia, 43600 Bangi, Selangor, Malaysia.

Tel: +603-8921 5606 E-mail: ali@ukm.edu.my

Mohd Adib Ismail

Faculty of Economics and Management, Universiti Kebangsaan Malaysia, 43600 Bangi, Selangor, Malaysia.

Tel: +603-89213301 Email: mohadis@ukm.edu.my

\begin{abstract}
To ensure that the countries produce halal products in order to remain in the international market, then they must make sure that they remain competitive in the market. Therefore, this study was to measure the competitiveness of the halal industry in the Maghreb countries which consist of five countries, namely Algeria, Libya, Mauritania, Morocco and Tunisia. The methodology of this study was using halal market share in the country and revealed comparative advantage (RCA). The study found that Mauritania is the most competitive country for halal industry because of it has the highest RCA value and followed by Morocco and Tunisia. While the countries that have lower competitiveness are Algeria and Libya. Therefore, the government and industry should plays a role to improve the competitiveness of their national halal industry and to ensure they remain competitive in the international halal market.
\end{abstract}

Keywords: Competitiveness; Halal industries; Halal market share, Maghreb countries; Revealed comparative advantage

\section{Introduction}

Nowadays, the halal market is recognized as one of the most important sectors in the world. Halal industry has a great potential in the domestic and international markets (Aziz \& Vui, 2012). Halal market has also become a new market force that develops rapidly in the market that affects and alters the perception of how business should be conducted (Lada et al., 2009).

The worldwide Muslim population is expected to increase from 1.6 billion in 2010 up to 2.2 billion people by 2030. 26.4 percent of 8.3 billion people of the total world population in 2020 are Muslims (Grim \& Karim, 2011). By 2050, the Muslim population is estimated to be at about 2.6 billion people and represents almost 30 percent of the world population.

According to the report by Pew Research Centre's Forum on Religion and Public Life (Grim \& Karim, 2011), 79 nations will have more than a million Muslim citizens in 2030, compared to 72 countries currently. A huge number of Muslims who adhere to Islamic dietary laws (halal) have led to an increase in global demand for halal products. Although this 
figure is based on the total Muslim population of the world, there is also demand from nonMuslims for halal industry, which has not been taken into account (MITI, 2010). This is supported by Talib and Ali (2009) who said that halal products not only gain ground among Muslim consumers but it also attracts other consumers who are aware and concerned with the hygiene and safety of products in addition to the quality of the product.

According to Grim \& Karim (2011), the countries that have the highest percentage of Muslim population among Muslim-majority countries are the Middle East and North Africa. Worldwide, the Muslim population is expected to grow at double of the scale of non-Muslim population over the next 20 years. The average annual rate of growth for Muslim is 1.5 percent, meanwhile for non-Muslim it is only 0.7 per cent (Grim \& Karim, 2011). In fact, more than half of the 20 countries in that region have more than 95 percent of the Muslim population (Azman \& Masron, 2012).

Maghreb countries consist of five countries, namely Algeria, Libya, Mauritania, Morocco and Tunisia. Maghreb countries, which are situated in the western part of North Africa, have the population of 92 million people (World Development Indicators, 2013) and almost 100 per cent are Muslims (CIA World Factbook, 2013). Due to this reason, there is a huge market for halal industry. The size of the overall economy of the Maghreb countries amounted to USD 118520 million (2010) and has increased to USD 247977 million (2012) (World Development Indicators 2014).

Organization for Economic Co-operation (OECD) and define competitiveness as the ability of the state, industry or firm in generating revenue and employment factor that are highly sustained in the conditions of constant exposure to international competition (Hatzichronoglou, 1996). Rostow (1999) and Raf (2012) define competitiveness as the ability to produce goods or services that are equivalent to the international goods and services.

According to Porter (1998) competitiveness for the firm means the firm is able to provide advantages or benefits in terms of costs and benefits resulting from inequality. A firm will enjoy cost benefits when the firm is able to produce goods or services at a lower cost compared to the other competitors in the same industry. For the benefit of inequality, if the firm can handle its competitor's advantage and strength in terms of the unique product or service, the firm can be qualified as competitive in terms of differential. Both types will contribute in enhancing the overall competitiveness of firms that benefits the customer and will generate maximum profits for the firm (Idris et al., 2007)

From the perspective of the country, Scott and Lodge (1985) defines competitiveness as the "country's ability to create, produce, and distribute products and services" in the international economy. Porter (1990) then defines competitiveness as the ability of a country to design and create goods and services in the market, the price and also the characteristics for non-price that makes the package more attractive than its competitors.

Competitiveness is also referred as the ability of a country in performing its best in terms of economic well-being of the population and its relative trade performance compared to other countries (Ian et al., 2007). Fagerberg (1988) defines competitiveness as the ability of a country in its goals' realization of the economic policy, especially in income's growth and employment without facing difficulties in balance of payment.

According to Rahmana (2009) competitiveness can also be described as the capability to sustain its share of market. This ability is determined by factors of supply in a timely manner and at a competitive price. A timely supply and competitive price are influenced by two factors, namely flexibility (the ability to make adjustments to the user's desires) and 
management of product differentiation. The size of the market shares will also change according to the tastes of consumers.

According to Kotler (1997), market share can measure the difference of the marketing activities performance or operations between firms. The total sales of the firm compared to its competitors will show how competitive the firm is. If its market share increases, it shows their firms are more competitive than its competitors, and vice versa.

Market shares are also defined as the market share held by firm, or corporation to the total of sales in the market. This is because the market share indicates the percentage of a firm selling its products in the market and it can be used as an important mechanism to determine the marketing strategy (Raikes \& Heubrock, 1976). Market share is also an indicator for the firm that shows the ability of the firms in dominating the market and the firm's position itself in the market. Based on the level of market share, the firm position in the market can be determined whether it will be the market leader or market challenger, or simply as a market follower (Kotler, 1997).

In measuring the share of the export market, the two most common methods used are Revealed Comparative Advantage (RCA) and net exports index (NEI). These methods are the popular methods to measure the competitiveness of the industry. RCA approach which was pioneered by Balassa (1965) assumes that the comparative advantage can be observed from the last trading data. This RCA theory can measure index change in comparative advantages. The positive impact of trade liberalization and development can also be measured using RCA (Bender \& Li, 2000).

According to Shafaei (2007) RCA can measure the ability of exports in which export quantities for certain commodities, is divided into the country's total exports, compared to the global exports of the same commodity divided by the total global exports. As compared to the export competitiveness index such as Boston
Consulting Group (BCG) and Foreign Direct Investment Index (Ismail \& Radam, 2004), the information data required in measuring the RCA is only the export information. It has also been used to measure the change in the pattern of exports in the country (Leow \& Normee, 2009). Meanwhile Sudirman and Djulius (2010) have used RCA to measure the competitiveness of olefins petrochemical industry in Indonesia. RCA method can also be used to look at the economic impact of China in Southeast Asia (Coxhead, 2007).

\section{Methodology}

There are many methods of measurement used in measuring competitiveness. For this research, there are two methods, namely market share and RCA, are used. The market share technique is used in measuring halal industry competitiveness in the country, while the RCA is used in measuring the share of export markets to gauge international competitiveness.

\section{Country's Market Share}

Market share in this country is used to measure the level of competitiveness of the halal industry in the country as compared to the overall industry in the country. This method is intended to look at the trend of the halal industry competitiveness in those countries whether it is an increase, a decrease or a level off.

Market share is measured as:

$$
M S_{i j}=\frac{X_{i j}}{M_{j}} \times 100 \%
$$

Where:

$$
\begin{aligned}
& \mathrm{MS}_{\mathrm{ij}}=\text { Market share of I country at J market } \\
& \mathrm{X}_{\mathrm{ij}}=\text { Export of I country to J market } \\
& M_{j}=\text { Total Import of } J \text { market }
\end{aligned}
$$




\section{Revealed Comparative Advantage}

According to Shafaei (2009) RCA can measure the ability of exports in which export quantities for certain commodities is divided into country's total exports, compared to the global exports of the same commodity divided by the total global exports. If the RCA is greater than $1(\mathrm{RCA}>1)$, then the country has a comparative advantage in that product and has a strong competitive edge. However, if the RCA is less than one (RCA $<1$ ), the country will suffer losses as compared to the product or in other words, it has a weak competitiveness (Tulus, 2001). However, if a country does not export the goods, then the RCA for the goods is 0 .

RCA can be measured as:

$R C A_{a}^{i}=\frac{X_{a}^{i} / X_{t}^{i}}{X_{a}^{w} / X_{t}^{w}}$

Where:

$$
\begin{aligned}
& X_{a}^{i}=\text { Export product A of country I } \\
& X_{t}^{i}=\text { Total of export of country I } \\
& X_{a}^{w}=\text { Total export for product A } \\
& X_{t}^{w}=\text { Total world export }
\end{aligned}
$$

\section{Results \& Discussion}

Using the two equations which are equation market share and market share of exports, the competitiveness of the country's halal industry for the Maghreb country can be measured. The results are as follows:

\begin{tabular}{cccc} 
Table 1: Market share of halal industry in the country \\
\hline Country & Year & $\begin{array}{c}\text { Market share of } \\
\text { halal industry in the } \\
\text { country }(\%)\end{array}$ & $\begin{array}{c}\text { Average } \\
(\%)\end{array}$ \\
\hline Algeria & 2010 & 4.30 & 3.49 \\
& 2011 & 3.23 & \\
\hline Libya & 2012 & 2.93 & 0.36 \\
& 2010 & 0.05 & \\
\hline Mauritania & 2011 & 0.41 & 91.37 \\
& 2012 & 0.64 &
\end{tabular}

\begin{tabular}{llll} 
& 2012 & 68.67 & 76.08 \\
Morocco & 2010 & 74.62 & \\
& 2011 & 78.12 & \\
\hline Tunisia & 2012 & 75.49 & 44.91 \\
& 2010 & 48.95 & \\
& 2011 & 53.54 & \\
& 2012 & 32.24 & \\
\hline
\end{tabular}

Based on table 1, market share of halal industry for Algeria continuously decreases while halal market share for Libya increases from 2010 to 2012. Market shares of halal industry for Mauritania, Morocco and Tunisia have increased in 2011 but decreased in 2012. The higher the values of the halal market share in the country, the more competitive the halal industry in that country. Based on the table 1, countries with the highest average of halal market shares in the country are Mauritania (91.37\%), followed by Morocco (76.08\%) and Tunisia (44.91\%). The lowest average value of halal market shares are Algeria (3.49\%) and Libya (0.36\%). However, this marker share not completely represents the real competitiveness of halal industry for the

\begin{tabular}{|c|c|c|c|}
\hline Country & Year & $\begin{array}{c}\text { Revealed } \\
\text { Comparative } \\
\text { Advantages } \\
\text { (RCA) }\end{array}$ & $\begin{array}{c}\text { Average } \\
(\%)\end{array}$ \\
\hline \multirow[t]{3}{*}{ Algeria } & 2010 & 0.135 & 0.0732 \\
\hline & 2011 & 0.0479 & \\
\hline & 2012 & 0.0361 & \\
\hline \multirow[t]{3}{*}{ Libya } & 2010 & 0.0007 & 0.0031 \\
\hline & 2011 & 0.0051 & \\
\hline & 2012 & 0.0034 & \\
\hline \multirow[t]{3}{*}{ Mauritania } & 2010 & 9.4015 & 4.1180 \\
\hline & 2011 & 1.4883 & \\
\hline & 2012 & 1.5141 & \\
\hline \multirow[t]{3}{*}{ Morocco } & 2010 & 4.5039 & 2.5602 \\
\hline & 2011 & 1.7750 & \\
\hline & 2012 & 1.4018 & \\
\hline \multirow[t]{3}{*}{ Tunisia } & 2010 & 1.9306 & 1.1271 \\
\hline & 2011 & 0.9645 & \\
\hline & 2012 & 0.4863 & \\
\hline
\end{tabular}
country. Therefore, RCA method was used to verify the result.

Table 2: Revealed Comparative Advantages (RCA) 
The higher the market share of the country's exports, the more competitive it is in the global halal industry. According to table 2 the countries with the highest average RCA values are Mauritania (4.12), followed by Morocco (2.56) and Tunisia (1.13). The countries with the lowest RCA values are Algeria (0.07) and Libya (0.003).

If the RCA value is greater than $1(\mathrm{RCA}>1)$, then the country has an advantage in that product and a higher competitive edge. However, if the RCA value is less than one $(\mathrm{RCA}<1)$, then the country suffers losses as compared to the product or in other words, it has a weak competitiveness (Tulus, 2001). Therefore the countries that have higher or stronger competitiveness are Mauritania, Morocco and Tunisia, while the countries that have lower or weaker competitiveness are Algeria and Libya.

\section{Conclusion}

In conclusion, the most competitive country is Mauritania due to its highest RCA followed by Morocco and Tunisia, while the most uncompetitive country in the halal industry is Libya. The countries that have higher or stronger competitiveness are Mauritania, Morocco and Tunisia, while the countries that have lower or weaker competitiveness are Algeria and Libya.

Competitiveness is important in ensuring the industry or country to maintain its position or to compete in a market. A competitive country can remain in the market while the countries that are not competitive will be eliminated. Therefore, every country needs to improve the competitiveness of their countries to ensure that they can compete in the global halal market.

Among the measurement taken to improve the competitiveness of halal industry is to obtain the recognition of halal logo. By implementing the certification, the quality of the products to be produced will be assured compared to products without halal status (Talib \& Ali, 2009). Halal products have also received the attention of
non-Muslims because of its quality and hygiene that is confirmed through its halal certification. This can help countries to increase their exports to the market not for only Muslims but nonMuslims as well.

The government also needs to intervene in this case to help in expanding the halal industry in their countries. Mattson and Eastson (2000) stated that government agencies play an important role in helping industry development in the country. Policies implemented by the government should take all aspects into consideration, including the halal industry. The government should also establish a good relationship with other countries to allow local industries to export their products to these countries thus expanding their country's halal industry.

\section{References}

Aziz, Y.A. \& Vui, C.N. (2012). The role of halal awareness and halal certification in influencing non-muslims' purchase intention. $3^{\text {rd }}$ International Conference on Business and Economic Research, Indonesia, 1819-1830.

Azman, N. H. N., \& Masron, T.A. (2012). Halal development and food exports: evidence from Malaysia and MEACs. Prosiding Perkem VII, 318-324.

Balassa, B. (1965). Trade liberalization and revealed comparative advantage, The Manchester School, 33: 99-123.

Bender, S. \& Li, K.W. (2002). The changing trade and revealed comparative advantages of Asian and Latin American manufacture exports. Center discussion paper. Economic Growth Center No. 843.

CIA World Factbook. (2013). https://www.cia. gov/library/publications/the-world-factbook/

Coxhead, I. (2007). A new resource curse? Impacts of China's boom on comparative 
advantage and resource dependence in Southeast Asia. World Development, 35(7): 1099-1119.

Fagerberg, J. (1988). International competitiveness. Economic Journal, 98(391): 355-374.

Grim, B.J. and Karim, M.S. 2011. The future of the global muslim population: Projections for 2010-2030, Pew Research Center, Washington, DC.

Hatzichronoglou, T. (1996). Globalisation and competitiveness: relevant indicator. OECD Science, Technology and Industry Working Papers, No. 1996/05, OECD Publishing, Paris.

Ian, F. Martin, S. \& Mark, K. (2007). The competition of nation: why some countries prosper while others fall behind. World Development, 35(10): 1595-1620.

Idris, N.A., Shahdan, F., Bakar, N.A, Dan, A.R. \& Noor, M.A.M. (2007). Malaysia ke Arah Hab Makanan Halal Dunia. Dewan Bahasa dan Pustaka, Kuala Lumpur, Malaysia.

Ismail, M. M., \& Radam, A. (2004). Competitiveness of the Malaysian food processing industry. Universiti Putra Malaysia Press.

Kotler, P. (1997). Manajemen Pemasaran. Jakarta: PT. Prenhallindo.

Lada, S., Tanakinjal, G.H. \& Hosnin, H. (2009). Predicting intention to choose halal products using theory of reasoned action. International Journal of Islamic and Middle Eastern Finance and Management, 2(1): 66-76.

Leow, G.Y \& Normee, C.S. (2009). Benchmarking Malaysia's manufacturing exports competitiveness. Malaysian Journal of Economics Studies, 46(2): 175-200.

Mattson, L. G. \& Easton, G. (2000). International competitiveness and trade promotion policy from a network perspective. Journal of World Business, 35(3): 275-299.

Ministry of International Trade and Industry (MITI). (2011). Malaysian exports structure. www.miti.gov.my

Porter. (1990). The Competitive Advantage of Nation. The Free Press, New York.

Porter. (1998). On Competition. Boston: Harvard Business School Publishing.

Raf, M. (2012). Analisis eksplanatori faktor daya saing industri kecil (studi pada sentra industri kecil batik di kota Jambi). Jurnal Manajemen dan Kewirausahaan (Journal of Management and Entrepreneurship), 14(2): 91-101.

Rahmana, A. (2009). Peranan teknologi informasi dalam peningkatan daya saing usaha kecil menengah. Seminar Nasional Aplikasi Teknologi Informasi, 11-15.

Raikes, R., \& Heubrock, A. (1976). Impacts of market-share patterns on marketing firm costs. American Journal of Agricultural Economics, 58(4): 693-702.

Rostow, W. (1999). Stages of Economic Growth. Third Edition. New York: Hambridge University Press.

Scott, B. \& Lodge. (1985). US Competitiveness and the World Economy. Boston: Havard Business School.

Shafaei, R. (2009). An analytical approach to assessing the competitiveness in the textile industry. Journal of Fashion Marketing and Management: An International Journal, 13(1): 20-36.

Sudirman, I. \& Djulius, H. (2010). Dampak AFTA terhadap daya saing industri petrokimia olefin Indonesia. Jurnal Trikonomika, 9(2): 87-95. 
Talib, H.A. \& Ali, K.A.M. (2009). An overview of Malaysian food industry: the opportunity and quality aspects. Pakistan Journal of Nutrition, 8(5): 507-517.

Tulus, T. (2001). Perdagangan Internasional dan Neraca Pembayaran. Jakarta: Pustaka LP3ES.

World Development Indicators. (2013). http://dataworlbankorg/data-catalog/worlddevelopment-indicators. 
